International Journal of Current Advanced Research

ISSN: O: 2319-6475, ISSN: P: 2319 - 6505, Impact Factor: SJIF: 5.995

Available Online at www.journalijcar.org

Volume 6; Issue 5; May 2017; Page No. 3722-3723

DOI: http://dx.doi.org/10.24327/ijcar.2017.3723.0355

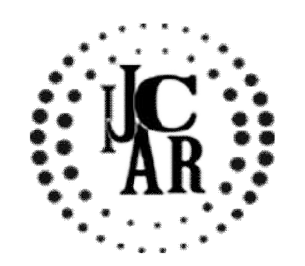

Research Article

\title{
PREFERENCE OF PROSTHODONTICS REPLACEMENT OPTION AMONG PARTIALLY EDENTULOUS PATIENT IN RURAL CHENNAI
}

\author{
Abhishek N., Anand and Vinay \\ Saveetha Dental College 162 Poonamalle High Road Chennai, 600077
}

A R T I C L E I N F O

\section{Article History:}

Received $20^{\text {th }}$ February, 2017

Received in revised form $12^{\text {th }}$ March, 2017

Accepted $15^{\text {th }}$ April, 2017

Published online $28^{\text {th }}$ May, 2017

Key words:

Missing Teeth, Replacement Option, Removable Denture, Fixed Bridge

\begin{abstract}
A B S T R A C T
Aim: To evaluate the preference of prosthodontics replacement option among partially edentulous patient of rural chennai.

Background: Teeth and their supporting structures are an integral part of the facial skeleton. They support and interact sensitively with other parts of the skull to provide a biological system to interact for chewing, speaking and expressing emotions. The loss of teeth can result in significant disabilities such as mastication, phonetics and aesthetics.The overall awareness of dental treatment and replacement of missing tooth is very low among the people of rural chennai so this research is done to determine the awareness of prosthodontic replacement option among the people in rural chennai
\end{abstract}

Reason: the number of edentulous patients are high so this study was aimed to methodically evaluate the preference of various prosthodontics replacement option for the replacement of missing teeth

Copyright $₫ 2017$ Abhishek N., Anand and Vinay. This is an open access article distributed under the Creative Commons Attribution License, which permits unrestricted use, distribution, and reproduction in any medium, provided the original work is properly cited.

\section{INTRODUCTION}

Teeth and their supporting structures form an integral part of the facial skeleton. They support and interact with other parts of the skull to interact for chewing, speaking and expressing emotions. Loss of the tooth is one of the most important factor which causes distress and devastating effect on the person's quality of life. Replacement of missing teeth by dental prosthesis depends upon many factors, among those factors awareness of the patients about dental prosthesis is one of the very important factor. Knowledge and awareness in the patients seeking prosthodontics treatment can help them to select more appropriate dental prosthesis. Requirements such as esthetics and comfort are considered more important in selection of dental prosthesis and also replacement of anterior is considered more important than posterior teeth by some patients. Other factors like age, gender, socio economic status, number of missing teeth are also very significant in selection of dental prosthesis. With the rapid improvement in oral health and the reduction of edentulism in many countries, increasing numbers of people are retaining more teeth later in life. Knowledge of the subjects regarding prosthodontics treatment may play a role in their acceptance of the prostheses.

*Corresponding author: Abhishek N

Saveetha Dental College 162 Poonamalle High Road Chennai, 600077

\section{MATERIALS AND METHODS}

A study was conducted to determine patient's awareness towards artificial prosthesis and preference of need of prosthesis. A questionnaire consisting of 8 multiple choice questions regarding the preference of prosthodontic replacement option was prepared. The survey was conducted online and through questionnaires and have a total of 100 participants who are partially edentulous.

Are you aware that you have missing teeth?
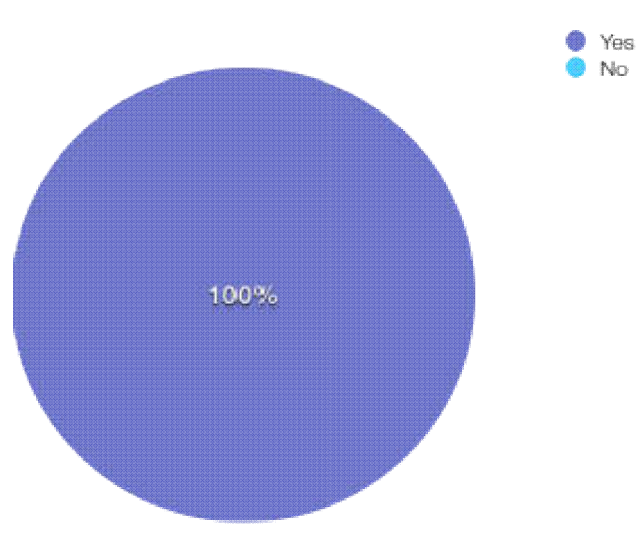
For how long do you have missing teeth?

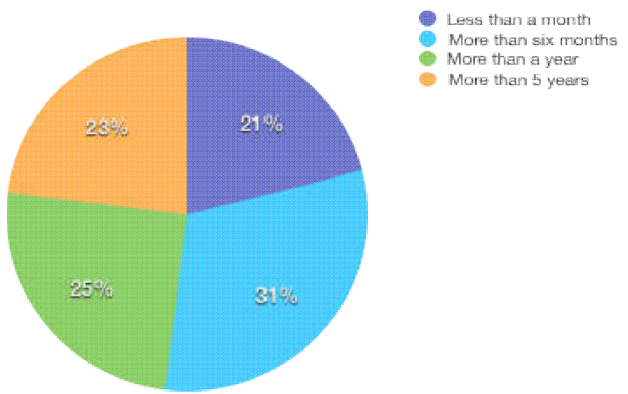

Are you willing to replace your teeth?

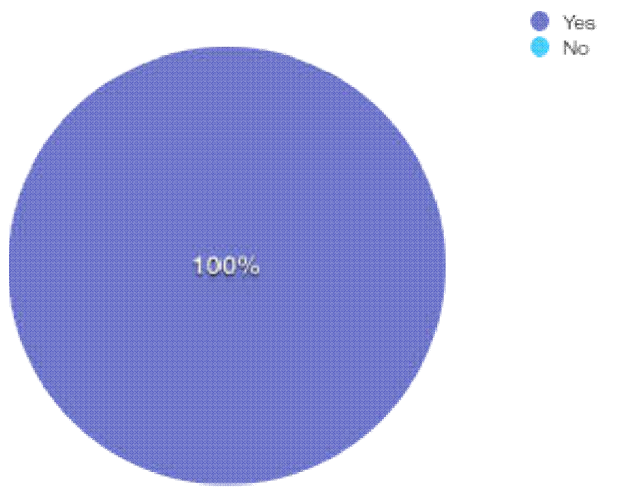

Which of the following have you heard of?

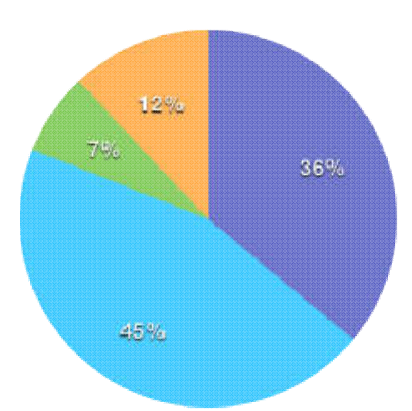

Which is your most preferable method of replacing your teeth?

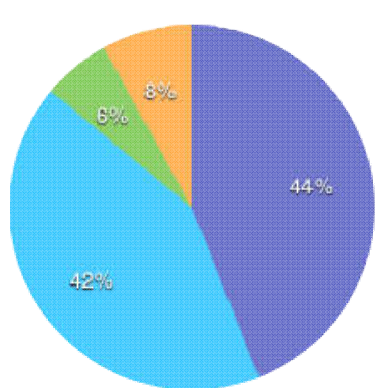

If not replaced the why?

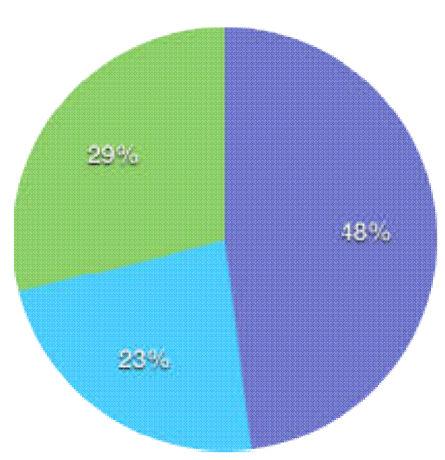

What is the source of information for prosthetic option?

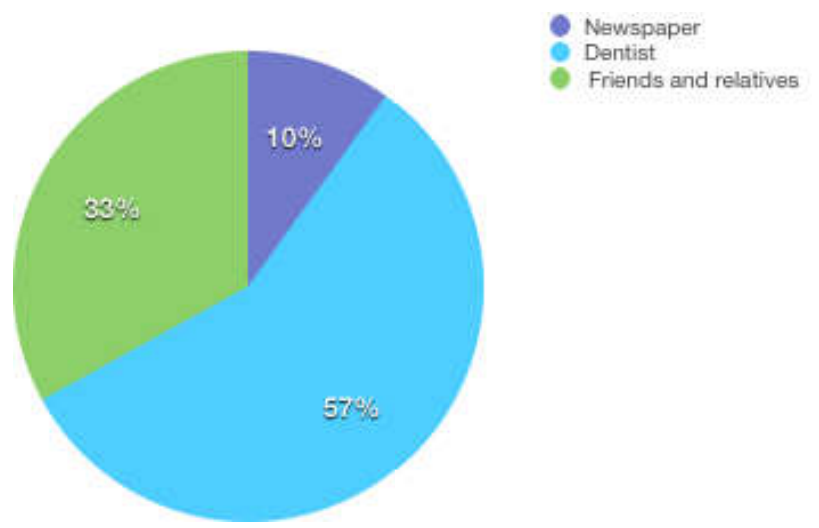

\section{CONCLUSION}

The patient awareness for different treatment options for missing teeth was found very low. Several studies have been conducted to show the patients' awareness about implants is very low. Many patients are not motivated to replace the missing teeth immediately even though they are willing to replace the missing tooth their decision to replace the tooth is being delayed. Apart from this, community based oral health education $\mathrm{u}$ should be conducted to improve patient's oral health knowledge.

\section{DISCUSSION}

In general, prosthodontics is concerned with the artificial replacement of partial or complete loss of teeth and oral function due to tooth or tissue damage. Prosthodontic treatment involves the replacement of few missing teeth in a healthy but incomplete dentition[1]. Several studies have been conducted to show the patients' awareness about implants [4]. Patient's knowledge and awareness about dental prosthesis is one of the key factors in selection of any particular dental prosthesis [2]. Factors like age, gender, education, socioeconomic status, and number of missing teeth are also important factors regarding awareness about different dental prosthesis [3]

\section{References}

1. Assessment of Prosthodontic Preferences Among Ageing Population In Alkharj Town (Kingdom Of Saudi Arabia): A Survey Based Study Mohammed Zaheer Kola et al

2. Rustemeyer J, Bremerich A. Patients' knowledge and expectations regarding dental. Implants: assessment by questionnaire. Int J Oral Maxillofac Surg 2007; 36: 814-17. 10

3. AbdurahimanVT, Abdul Khader M, Sanju John Jolly. Frequency of partial edentulism and awareness to restore the same: a cross sectional study in the age group of 18-25 years among Kerala student population. J Indian Prosthodont Soc 2013; 13: 4665

4. Knowledge and Awareness among Patients about Dental Implants Dr. M.P. Santhosh Kumar M.D.S., Department of Oral and Maxillofacial Surgery Saveetha Dental College And Hospital 162, Poonamallee High Road, Velappanchavadi, Chennai Tamilnadu 600077, India 